\title{
Effect of abscisic acid on the maturation of olive trees cv. Arbequina
}

\author{
Efecto del ácido abscísico sobre la maduración en \\ olivos var. Arbequina
}

Américo Contreras, Thomas Fichet Lagos ${ }^{1}$

\section{SUMMARY}

Interventions which accelerate the fruit maturation of olives planted in cold climates are necessary to advance the harvest and not allow the fruit to be exposed to early freezes which may have negative effects on the quality of the oil. In Autumn (28 April) 2006 we applied 0, 100, 200, 300 and $400 \mathrm{mg} \cdot \mathrm{L}^{-1}$ abscisic acid (ABA) to trees of the variety of Arbequina at the beginning of veraison in an orchard in Melipilla, Metropolitan Region, Chile, in order to evaluate its effect on the acceleration of fruit maturation. The experimental design was completely randomized; the means of the treatments were compared by ANOVA and Tukey's test ( $\mathrm{p}<0.05$ ). The application of ABA produced a strong defoliation of the trees, together with a marked fruit fall, especially at 300 and 400 $\mathrm{mg} \cdot \mathrm{L}^{-1}$. Fruit maturation was retarded, expressed as a delay in the development of color for trees treated with $400 \mathrm{mg} \cdot \mathrm{L}^{-1} \mathrm{ABA}$. The treatments did not produce an effect on the oil content measured as a proportion of dry weight. The following year (2007), those trees treated with 300 and $400 \mathrm{mg} \cdot \mathrm{L}^{-1}$ showed a significant reduction in fruit harvested per tree, which may be due to an effect of the ABA applied on the processes of induction or initiation of bud differentiation.

Key words: differentiation, maturation. Olea europaea $\mathrm{L}$.

\section{RESUMEN}

Labores que generen anticipos en la maduración de la fruta de olivos plantados en climas fríos, son necesarias para adelantar las cosechas y no exponer a la fruta a heladas tempranas que pudieran tener efectos negativos en la calidad del aceite. Durante el otoño (28 de abril) de 2006, en un olivar de la variedad Arbequina (Comuna de Melipilla, Región Metropolitana, Chile), se aplicó al momento de envero: 0, 100, 200, 300 y $400 \mathrm{mg} \cdot \mathrm{L}^{-1}$ de ácido abscísico (ABA) para evaluar su efecto en el adelanto de la maduración de los frutos. El diseño experimental fue completamente al azar y las medias de los tratamientos se compararon con la prueba de Tukey $(p \leq 0.05)$. La aplicación de ABA provocó una fuerte defoliación en los árboles, junto con una marcada caída de frutos, principalmente para 300 y $400 \mathrm{mg} \cdot \mathrm{L}^{-1}(p \leq 0.05)$. Además se retrasó la maduración de la fruta, expresado en la demora del desarrollo de color para los árboles tratados con $400 \mathrm{mg} \cdot \mathrm{L}^{-1}$ de ABA. No hubo efecto de los tratamientos en el contenido de aceite en base a materia seca. Al año siguiente (2007), los árboles tratados el 2006 con 300 y $400 \mathrm{mg} \cdot \mathrm{L}^{-1}$ redujeron significativamente la cantidad de fruta cosechada por árbol, lo cual podría deberse a un efecto de la aplicación de ABA en el proceso de inducción o inicio de la diferenciación de las yemas.

Palabras clave: diferenciación, maduración. Olea europaea $L$.

\section{Introduction}

Abscisic acid (ABA) is a plant hormone belonging to a class of isoprenes commonly called sesquiterpenoids (Nambara and MarionPoll, 2005). The exogenous application of ABA stimulates the development of color in grapes and accelerates pigmentation of anthocyanins (Ban $e t$ al., 2000), changes the color of the epidermis and softens bananas (Jiang et al., 2000) and favors the accumulation of sugars in the pulp of persimmons (Nakano et al., 1997). In olives, ABA concentration increases at the beginning of fruit maturation and its exogenous application stimulates this increase (Beltrán et al., 2004).

There is greater expression of ABA In plants under water restriction (Schroeder and Nambara, 2006), similar to what occurs with controlled deficit irrigation; in olives of the Arbequina variety maturity is hastened compared to non-stressed plants, along

1 Cien. Inv. Agr. Universidad de Chile, Casilla 1004.

Direct correspondence to: tfichet@uchile.cl 
with a greater facility of oil extraction (Alegre et al., 2002). This behavior may be correlated with the high endogenous levels of ABA in the fruit, which may be responsible for the acceleration of fruit maturation (Beltrán et al., 2004).

The objective of this study was to evaluate the effect of ABA application at veraison on the maturation of olives for oil production. The working hypothesis was that the application of $\mathrm{ABA}$ at veraison will accelerate the synthesis and accumulation of lipids in the fruit, and thus produce early maturation.

\section{Materials and Methods}

\section{Plant material}

The study was performed between April, 2006 and May, 2007 in an orchard of 7-year old var. Arbequina olives in the Melipilla Community and Province of the Metropolitan Region, Chile (33 ${ }^{\circ}$ $48^{\prime} \mathrm{S}$; $71^{\circ} 05^{\prime} \mathrm{W}$, altitude $205 \mathrm{~m}$ ). The orchard uses organic management and mechanical (drip) irrigation $1 \mathrm{~m}$ from the trees at $4 \mathrm{~L} \cdot \mathrm{h}^{-1}$. Trees are planted in a north-south orientation with a spacing of $6 \times 2 \mathrm{~m}$. The area has a Mediterranean climate, with most rain between May and September; average annual precipitation is $400 \mathrm{~mm}$. Maximum evapotranspiration occurs in January, with a mean ET0 of $5.5 \mathrm{~mm} \cdot$ day $^{-1}$. January is also the warmest month, with a mean maximum of $30^{\circ} \mathrm{C}$ and a mean minimum of $5.5^{\circ} \mathrm{C}$. July is the coldest month, with mean maximum $17^{\circ} \mathrm{C}$ and mean minimum of $2^{\circ} \mathrm{C}$. On April 28, 2006 (Autumn) we applied abscisic acid (ABA, Valent BioSciences Corporation, 5\% $\mathrm{v} / \mathrm{v}$ ) to five trees per treatment at the beginning of veraison (the color produced when the epidermis of the olive fruit accumulates anthocyanins) (Table 1).

Table 1. ABA treatments and the $\mathrm{pH}$ of the solutions applied in var. Arbequina olives at the beginning of veraison (28 April 2006).

\begin{tabular}{ccc}
\hline Treatment & $\begin{array}{c}\text { Concentration } \\
\text { of ABA }\end{array}$ & $\begin{array}{c}\mathrm{pH} \text { of } \\
\text { solution }\end{array}$ \\
\hline 1 (Control) & $0 \mathrm{mg} \cdot \mathrm{L}^{-1}$. & 6.5 \\
2 & $100 \mathrm{mg} \cdot \mathrm{L}^{-1} \cdot$ & 4.2 \\
3 & $200 \mathrm{mg} \cdot \mathrm{L}^{-1} \cdot$ & 4.6 \\
4 & $300 \mathrm{mg} \cdot \mathrm{L}^{-1} \cdot$ & 4.5 \\
5 & $400 \mathrm{mg} \cdot \mathrm{L}^{-1}$. & 4.4 \\
\hline
\end{tabular}

For measurements of oil content based on dry weight, fruit humidity and the Ferreira Index, we selected fruits from the central section of the tree (approximately 100 olives for each tree) on each sampling date. The material for histological sections was from shoots located in the central section of the tree. Buds from the central section of the shoots were used.

\section{Variables}

\section{Fruit fall}

We counted the number of fallen fruit from the time the treatments were applied until harvest (10 June 2006).

\section{Accumulation of oil}

We took fruit samples every 7 days, from the beginning of the experiment until harvest, to evaluate the oil content of the pulp expressed as percentage of dry weight, using the Soxhlet method (Frías et al., 1970 fide Jiménez et al., 2000).

\section{Ferreira Index}

For the measurement of color at the time of experimental harvest, which was made to coincide with the commercial harvest (oil content close to $45 \%$ of dry weight), we collected 100 fruit from the central section of the tree in order to determine the degree of coloration at harvest time according to the Ferreira Maturity Index (Beltrán et al., 2004), habitually used as an indicator of fruit maturity. Each fruit was assigned to one of the categories in Table 2.

Table 2. Classes of the Ferreira Maturity Index.

\begin{tabular}{|c|c|}
\hline Class & Characteristics \\
\hline 0 & Skin intense green. \\
\hline 1 & Skin yellowish-green. \\
\hline 2 & $\begin{array}{l}\text { Skin green with pink spots in less than half of the } \\
\text { fruit. Beginning of veraison. }\end{array}$ \\
\hline 3 & $\begin{array}{l}\text { Skin pink or purple in more than half of the fruit. } \\
\text { End of veraison. }\end{array}$ \\
\hline 4 & Skin black, pulp white. \\
\hline 5 & Skin black, less than half of pulp purple. \\
\hline 6 & $\begin{array}{l}\text { Skin black and pulp purple; purple does not reach } \\
\text { the pit. }\end{array}$ \\
\hline 7 & Skin black and pulp purple to the pit. \\
\hline
\end{tabular}


The Ferreira Maturity Index (FMI) was obtained using the formula:

$$
\begin{gathered}
M I=\left(A^{*} 0+B^{*} 1+C^{*} 2+D^{* 3} 3+E^{* 4}+\mathrm{F}^{* 5}\right. \\
\left.+\mathrm{G}^{* 6}+\mathrm{H}^{*} 7\right) / 100,
\end{gathered}
$$

where A, B, C, D, E, F, G and $\mathrm{H}$ are the numbers of fruit in classes $0,1,2,3,4,5,6$ and 7, respectively.

\section{Histological sections}

Beginning on 28 April, 2006 we sampled buds every three weeks for five months until 22 August 2006, in order to determine the time of initiation of floral differentiation. The samples were obtained from the control trees.

Eight shoots from the previous spring were sampled from each tree, four with western and four with eastern exposure. Four buds were collected from each branch, beginning with the third apical bud (with high probability of being reproductive buds according to Fabbri and Alerci (1999)) for histological sections, in order to determine the process of floral differentiation. Buds were fixed and preserved in FAA (formaldehyde, 70\% ethanol and glacial acetic acid $(5: 90: 5 \mathrm{v} / \mathrm{v})$ until sectioned.

Buds were dehydrated in an ascending series of ethanol concentrations (70\%, $80 \%$ and $90 \%$ for $30 \mathrm{~min}$ each) and then included in JB4 plastic (PolyScience Inc., USA). The $8 \mu \mathrm{m}$ thickness sections were cut with a rotation microtome (Leitz Model 1516, Germany), with glass knives. Tissues were stained with Schiff reagent and toluidine blue.

We used the method of Castillo and Rapoport (2003) to determine the physiological state of the buds, focusing specifically on the developmental stages of the apex of development of the olive bud up to the beginning of differentiation (Table 3).

\section{Production}

On 10 June 2006 all fruit were harvested and weighed separately for each tree. The productive efficiency was expressed as $\mathrm{kg}$ fruit $\cdot \mathrm{cm}^{-2}$ TCSA (trunk cross sectional area); final yield was expressed as number of fruit $\cdot \mathrm{cm}^{-2}$ TCSA. On 12 May 2007 the trees treated in 2006 were harvested again, to determine variation with respect to the expected productivity. We also counted and weighed all fruit. These data were also expressed as $\mathrm{kg}$ fruit $\cdot \mathrm{cm}^{-2}$ TCSA and number of fruit $\cdot \mathrm{cm}^{-2}$ TCSA.
Table 3. Developmental stages of the apex of the olive bud.

\begin{tabular}{cl}
\hline State & \multicolumn{1}{c}{ Description } \\
\hline A & $\begin{array}{l}\text { Apex of reduced size. Presence of a tunic with two } \\
\text { rows. Leaf primordia inclined up to the apex. }\end{array}$ \\
B $\quad \begin{array}{l}\text { Apex dome shaped, well developed due to the presence } \\
\text { of initial stem cells. Presence of tunic with greater } \\
\text { number of cells than state A. }\end{array}$ \\
C $\quad \begin{array}{l}\text { Apex elevated, trapezoidal in form. } \\
\text { D }\end{array}$ \\
$\begin{array}{l}\text { Initial formation of the following node due to the } \\
\text { presence of small leaf primordia in the lateral sides of } \\
\text { the apex. As the leaf primordia grow, the new apical } \\
\text { meristem decreases its width. }\end{array}$ \\
\end{tabular}

\section{Experimental design and statistical analysis}

The experimental design was completely randomized, with five treatments and five replicates per treatment. We performed an analysis of variance and Tukey's a posteriori test to compare the means $(\mathrm{p}<0.05)$.

\section{Results and Discussion}

\section{Leaf and fruit fall}

From one week after the application of ABA until the fruit harvest, five weeks after application, there was considerable abscission of fruit and leaves, in both cases proportional to the concentration applied. Visual inspection determined that leaf fall occurred in branches with fruit; vegetative branches did not lose leaves, which probably occurred because the presence of fruit caused greater stress and sensitivity to ABA in leaves close to the fruit (Figure 1).

Figure 2 illustrates the evolution of fruit fall, which was greater and with a more pronounced maximum in trees treated with $300 \mathrm{or} 400 \mathrm{mg} \cdot \mathrm{L}^{-1}$ compared to the other treatments $(\mathrm{p}<0.05)$. Fruit fall was about $2 \%$ in the control and the treatment with $100 \mathrm{mg} \cdot \mathrm{L}^{-1} \mathrm{de}$ ABA. However, the other treatments produced more than $11 \%$ fruit fall, which represented about $1 \mathrm{~kg}$ of fruit per tree (Figure 3).

Our results differ from others reported in var. Manzanilla olives, in which application of 1000 and $2000 \mathrm{mg} \cdot \mathrm{L}-1$ ABA produced leaf abscision 6 days after treatment, but without fruit fall (Hartmann et al., 1968). Lower ABA concentrations induced neither leaf nor fruit fall. The difference may be due to the use of different isoforms of ABA which 


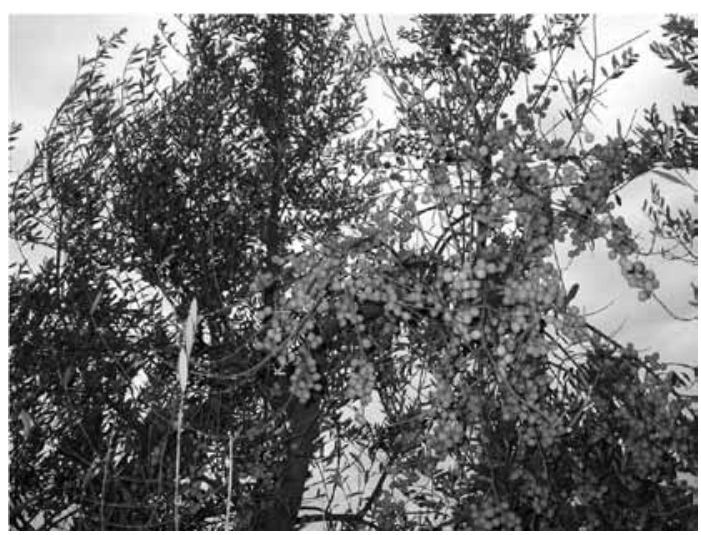

Figure 1. Olive tree after application of ABA $\left(400 \mathrm{mg} \cdot \mathrm{L}^{-1}\right)$, showing considerable defoliation in the areas with fruit production and almost no leaf fall in vegetative branches. differ in their biological activity (Zaharia et al., 2005); however, Kitsaki et al., (1999) reported that an ABA concentration of $100 \mathrm{mg} \cdot \mathrm{L}^{-1}$ produced $20 \%$ defoliation of shoots submerged in this solution.

\section{Oil accumulation}

No differences were observed in the proportion of oil accumulation (43-49\% of dry weight) that could be attributed to the application of ABA or to defoliation of the trees, even at the higher concentrations (Table 4). It may be that in this period there was little movement of photosynthates from the leaves to the fruit, which could explain why oil accumulation was not affected by the treatments. Another possibility is that fruit may have been able

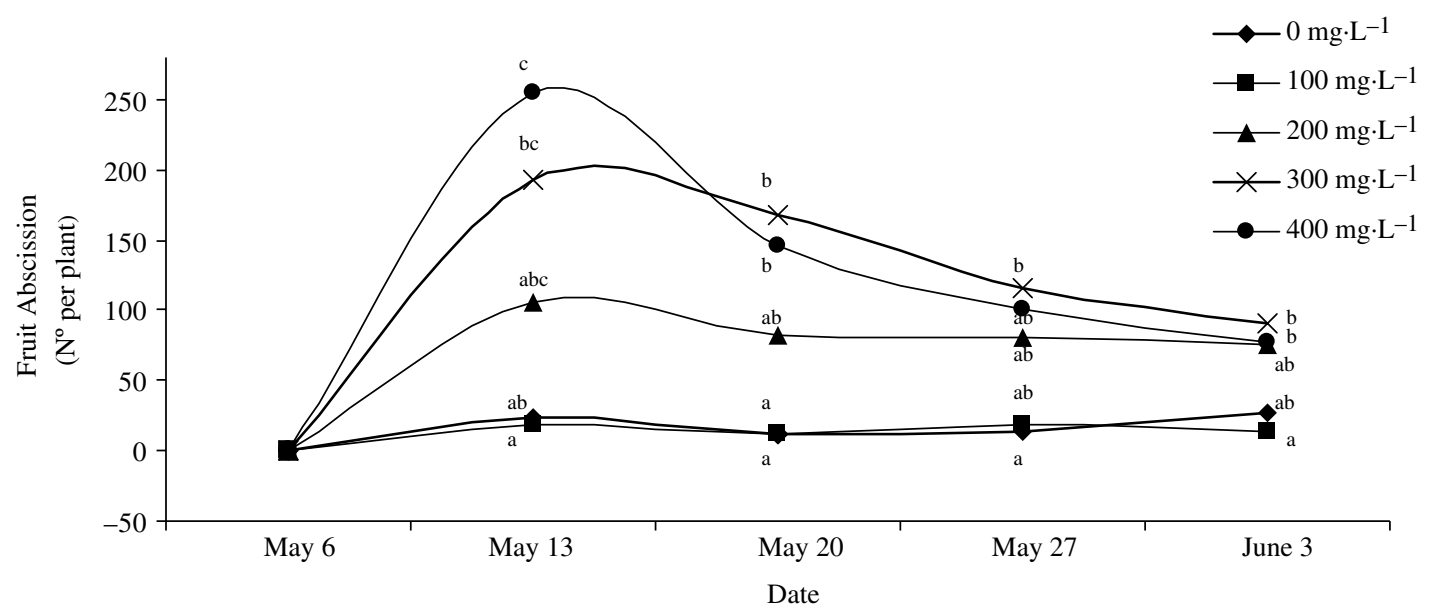

Figure 2. Evolution of fruit fall after application of ABA at the beginning of veraison (28 April 2006) to var. Arbequina olive trees. Means on the same date with different letters were significantly different $(\mathrm{p}<0.05)$.

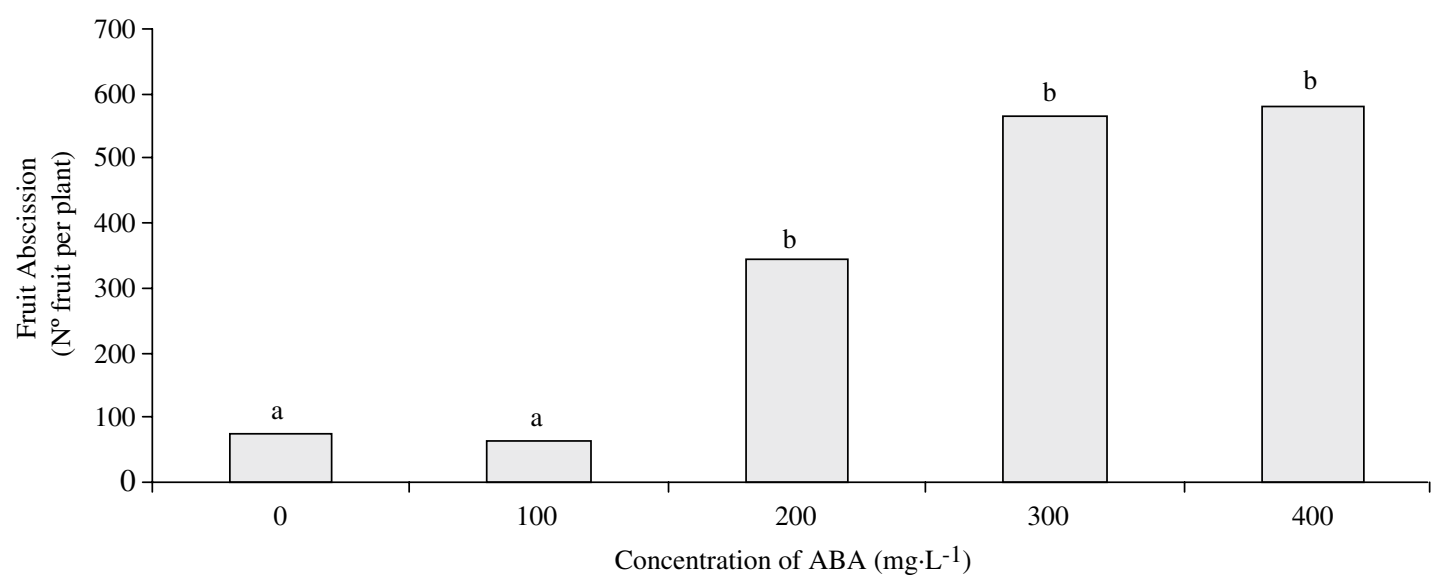

Figure 3. Accumulated fruit fall before harvest for different ABA treatments of var. Arbequina olive trees (12 June 2006). Means with different letters are statistically significant $(\mathrm{p}<0.05)$. 
Table 4. Changes in oil content based on dry weight on the different evaluation dates in olive fruits var. Arbequina treated with different concentrations of ABA.

\begin{tabular}{|c|c|c|c|c|c|c|}
\hline \multirow{2}{*}{$\begin{array}{l}\text { Treatment } \\
\left(\mathrm{mg} \cdot \mathrm{L}^{-1} \mathrm{ABA}\right)\end{array}$} & \multicolumn{6}{|c|}{ Percentage of oil based on dry weight $(\%)$} \\
\hline & 06-May & 13-May & 20-May & 27-May & 03-Jun & 10-Jun \\
\hline Control & 45.9 & 49.8 & 50.7 & 51.7 & 48.4 & 48.6 \\
\hline 100 & 45.9 & 45.9 & 52.9 & 51.9 & 45.5 & 47.4 \\
\hline 200 & 45.9 & 45.6 & 47.2 & 50.3 & 42.1 & 45.4 \\
\hline 300 & 45.9 & 47.1 & 46.1 & 49.9 & 47.7 & 44.9 \\
\hline 400 & 45.9 & 45.6 & 50.2 & 46.5 & $43 . .2$ & 42.7 \\
\hline
\end{tabular}

There were no statistically significant differences between treatments $(\alpha \leq 0.05)$.

to obtain photosynthates from nearby non-defoliated shoots (Conde et al., 2008). Tous et al. (1998) also indicated a maximum net accumulation of $47 \%$ oil for this variety, similar to our results.

\section{Ferreira Index}

The fruit of the control trees had an optimum Ferreira Index (near 3.5) at the moment of harvest, which is the recommended value for the harvest of olives for oil (Beltrán et al., 2004). However, the treatment with $400 \mathrm{mg} \cdot \mathrm{L}^{-1} \mathrm{ABA}$ was significantly different from the control (Figure 4). Visually the fruit from trees treated with $400 \mathrm{mg} \cdot \mathrm{L}^{-1} \mathrm{ABA}$ were still immature according to this index, showing less development of anthocyanin pigments.

The transition in color which fruit undergoes is one of the variables which allow its maturity to be measured. The degradation of the green color due to the destruction of the photosynthetic pigments is followed by a pigmentation which changes from pink to violet, sometimes appearing black, due to the accumulation of anthocyanin pigments in the epidermis of the fruit. In variety Arbequina only some of the cells of this zone have these pigments; thus the fruit tends to have a partial coloration in optimum conditions of development and maturation (Beltrán et al., 2004). This result indicates that the highest concentration of ABA we applied induced less color development, affecting the synthesis of anthocyanins in the fruit epidermis. This is probably due to a lower incorporation of carbohydrates in the fruit as a result of the defoliation of the tree, which would indicate that the reduction of photosynthates affected the synthesis of anthocyanins, as reported by Loussert and Brousse (1980) and Dussi (2007), but not the accumulation of oils, which our study verified.

It should be noted that immature olive fruit are green. When the fruit begins to mature, its photosynthetic activity decreases and the chlorophyll begins to disappear (Gandul-Rojas et al., 1999). Simultaneously, the concentration of carotenes begins a continuous decrease. However, when the fruit reaches maturity this fraction may disappear, remain constant or increase (Roca and MínguezMosquera, 2001a). As maturation proceeds in var. Arbequina the loss of chlorophyll is more notable than the loss of carotenes. Although both pigments have a similar level at the end of the maturation period, chlorophyll content is greater than that of the carotenes in all phases of the maturation process (Criado et al., 2007). The gradual loss of chlorophyll and carotenes will be more pronounced while the anthocyanins are increasing during the course of fruit maturation (Roca and Mínguez-Mosquera, 2001b). Anthocyanins are the pigments which give the olive fruit its final color (Agustí, 2008); a number of the genes involved in the anthocyanin pathway have been identified in olive fruit (Alagna et al., 2009). The color of grapes also depends on the pathway of anthocyanin synthesis (Boss et al., 1996). However, in contrast to our results in which an ABA concentration of $400 \mathrm{mg} \cdot \mathrm{L}^{-1}$ produced a retardation in coloration, in table grape variety Crimson the application of abscisic acid induced an increased coloration due to a greater accumulation of anthocyanins in the fruit epidermis (Peppi et al., 2006); there was also an activation of the genes in the anthocyanin pathway (Ban et al., 2000). 


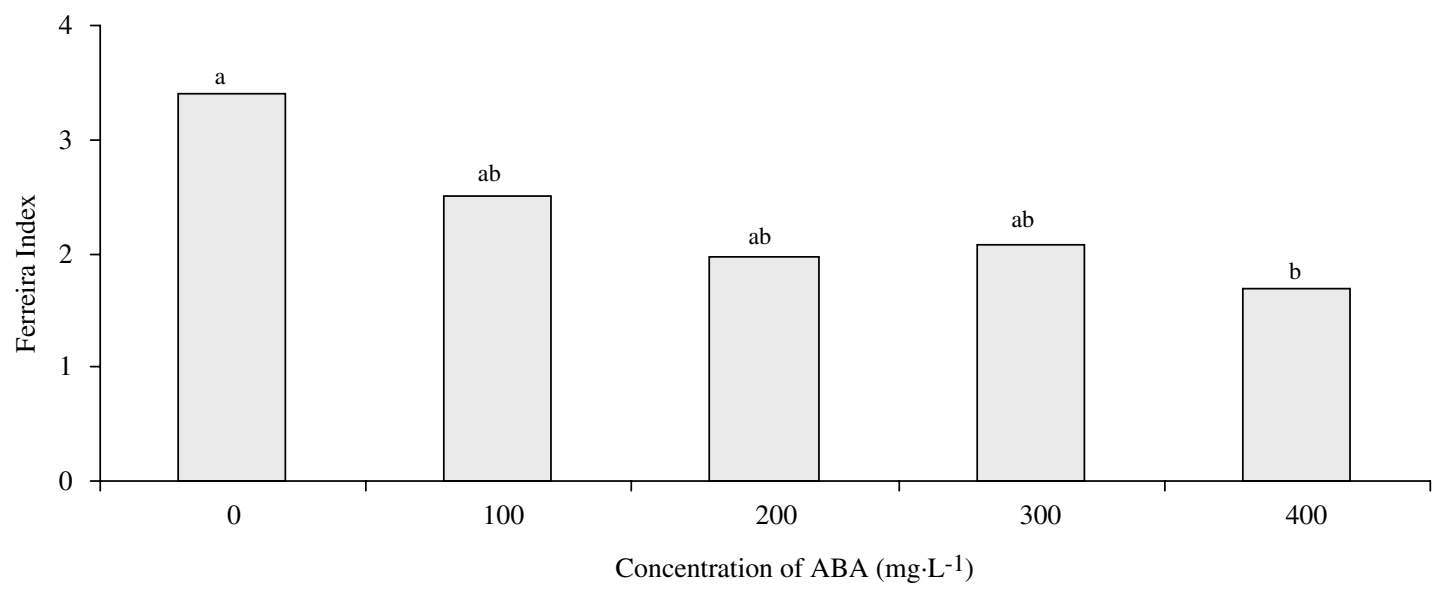

Figure 4. Ferreira Index at harvest (12 June 2006) in var. Arbequina olives. Bars with different letters are statistically different $(\mathrm{p}<0.05)$.

\section{Production}

In the 2006 harvest there were no significant differences in the productive efficiency or fruit yield between treatments. However, in 2007 productive efficiency was significantly less in the trees treated with300 y $400 \mathrm{mg} \cdot \mathrm{L}^{-1} \mathrm{ABA}$, and inferior to the values obtained for these treatments in 2006. Fruit yield increased between the two years for the control trees, however those treated with 100 and 200 $\mathrm{mg} \cdot \mathrm{L}^{-1}$ ABA did not have significant differences between years, while those treated with the highest concentrations (300 and $400 \mathrm{mg} \cdot \mathrm{L}^{-1}$ ) strongly decreased their fruit yield (Table 5). Taking into account that var. Arbequina has low alternation of production and that according to their age the trees were still in the stage of increasing production (Tous et al., 1998), the concentrations of 100 and $200 \mathrm{mg} \cdot \mathrm{L}^{-1} \mathrm{ABA}$ appear to have had a negative effect on flowering in the following year, since they did not produce a significant increase in fruit yield as did the control trees. The evaluation of fruit yield for 2007 showed that it was significantly greater for concentrations of 0 and $100 \mathrm{mg} \cdot \mathrm{L}^{-1}$ compared to concentrations of 300 and $400 \mathrm{mg} \cdot \mathrm{L}^{-1}$. This indicates that the application of the greatest concentrations of ABA had a negative influence on the fruit yield of these trees, probably due to the interference of ABA in the process of floral bud differentiation (Badr et al., 1970). This is confirmed by the fact that the buds were already beginning floral differentiation, a process known as evocation, when

Table 5. Production efficiency ( $\mathrm{kg}$ fruit.cm-2 TCSA) and fruit yield (number of fruits.cm-2 TCSA) for the two years evaluated.

\begin{tabular}{cccccc}
\hline \multirow{2}{*}{ ABA $\left(\mathrm{mg} \cdot \mathrm{L}^{-1}\right)$} & \multicolumn{2}{c}{$\mathrm{kg}$ fruit.cm-2 ASTT } & & \multicolumn{2}{c}{$\mathrm{N}^{\circ}$ of fruit.cm-2 ASTT } \\
\cline { 2 - 3 } \cline { 5 - 6 } & 2006 & 2007 & 2006 & 2007 \\
\hline 0 & $0.17 \mathrm{aA}$ & $0.38 \mathrm{aA}$ & $73.2 \mathrm{aA}$ & $155.2 \mathrm{bA}$ \\
100 & $0.26 \mathrm{aA}$ & $0.33 \mathrm{aA}$ & $105.8 \mathrm{aA}$ & $180.6 \mathrm{aA}$ \\
200 & $0.23 \mathrm{aA}$ & $0.24 \mathrm{aA}$ & $97.2 \mathrm{aA}$ & $114.9 \mathrm{aAB}$ \\
300 & $0.23 \mathrm{aA}$ & $0.09 \mathrm{bB}$ & $119.4 \mathrm{aA}$ & $45.3 \mathrm{bB}$ \\
400 & $0.22 \mathrm{aA}$ & $0.09 \mathrm{bB}$ & $116.7 \mathrm{aA}$ & $45.6 \mathrm{bB}$ \\
\hline
\end{tabular}

Different lower case letters indicate significant differences in treatments between the two years. Different uppercase letters indicate significant differences between means in one year $(\mathrm{p} \leq 0.05)$. 

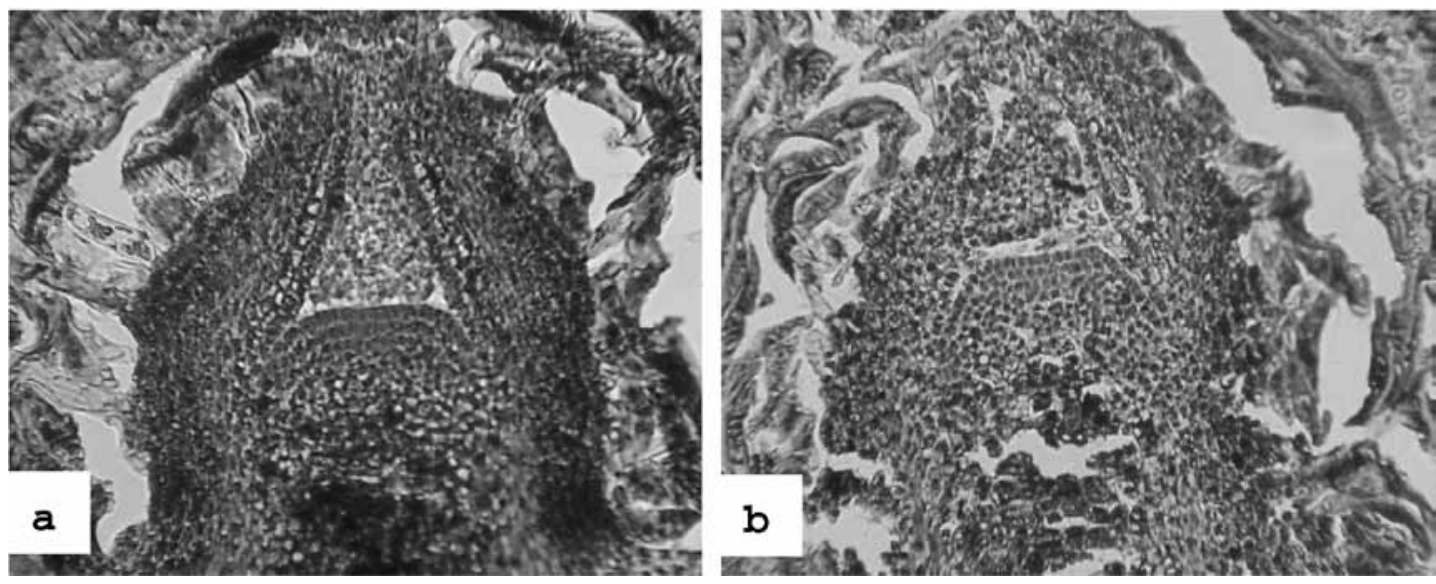

Figure 5. (a) Histological section of olive buds in developmental stage B obtained 21 April 2006, showing a well-developed domeshaped apex; b) flattened trapezoidal structure of the dome of a bud in developmental stage C, sampled on 22 de August 2006.

ABA was applied (Figure 5a); the presence of the tunic and corpus were well defined (Andreini et al., 2008). However, this process of floral differentiation practically did not change by 22 August 2006 (Figure 5b). Flowering of this variety occurs at the end of October, which indicates that the process of floral differentiation (formation of reproductive structures) occurs beginning in September, when the floral group begins to elongate (unpublished data).

The excessive loss of leaves in autumn, 2006 in the trees subjected to high concentrations of ABA affected their fruit yield in 2007, given the lower assimilation of photosynthates by the plant, probably reducing the carbohydrate reserves of the future floral buds and inducing a lower fruit yield in this year. According to Andreini et al. (2008), the differentiation of buds in olives depends on external and internal factors, thus it is expected that any factor which causes a decrease in photosynthesis (such as defoliation) will affect the formation of floral buds. The defoliated branches with fruit in 2006 were those which had a greater number of vegetative buds and fewer shoots with fruit in the following season (Figure 6).

The interference of ABA and leaf fall in fruit set was much more visible in the process of bud differentiation, since it affected the fruit set in the year after application (Table 3). This indicates an apparent intervention of ABA and later leaf abscission during the differentiation of vegetative buds. This is clearly seen in the two treatments with the highest ABA concentrations, in which the number of fruit in the autumn, 2007 harvest and production decreased significantly compared to the treatments with 0,100 and $200 \mathrm{mg} \cdot \mathrm{L}^{-1} \mathrm{ABA}$ (Table 3). Hackett and Hartmann (1964) reported that complete defoliation of olives in autumn completely inhibited the formation of inflorescences, which leads us to suspect the influence of the assimilation of photosynthates in this period, since according to Fabbri

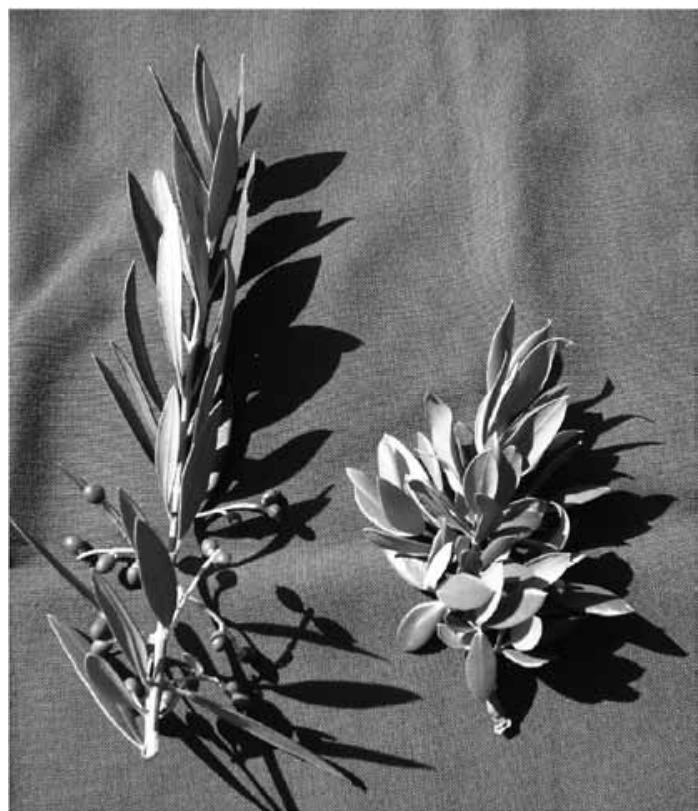

Figure 6. Left: shoot of olive of age one year without application of ABA and with fruit developing in December, 2006. Right, olive branch of age one year with application of ABA in April, $2006\left(400 \mathrm{mg} \cdot \mathrm{L}^{-1}\right)$ and later producing only vegetative shoots in December, 2006. 
and Benelli (2000) the accumulation of starch in olive roots as a product of the photosynthetic activity of the leaves would be very important in the phase of floral differentiation. Similar results have been reported in tangerines, associating the accumulation of carbohydrates in roots in autumn with later flowering in spring (Yao Li et al., 2003).

\section{Conclusions}

Applications of abscisic acid in high concentrations may generate a strong leaf abscission of leaves in var. Arbequina olives, which only lost leaves in branches with fruit. The highest concentration of this phytohormone used induced retarding of fruit coloration, but did not alter the oil content per dry weight. Fruit production in the next season was negatively affected by the higher concentrations, probably due to the interference of abscisic acid in the process of differentiation of the flowering buds. Given the lack of response in terms of early maturation and the low productive efficiency in the following year of the trees treated with larger doses, ABA treatment is not recommended for olives of the variety Arbequina.

\section{Acknowledgements}

The authors would like to thank Dr. Julio Retamales for a critical review of the manuscript.

\section{Literature Cited}

Alegre, S., J. Marsal, M. Mata, and J. Girona

2002. Regulated deficit irrigation in olive trees (Olea europaea

L.) for oil production. Acta Hort. 586: 259-262.

Agusti, M.

2008. Crecimiento y maduración del fruto. In: Azcón-Bieto, J

y M. Talón. (eds). 2008. Fundamentos de fisiología vegetal. Segunda edición. McGraw-Hill. Madrid. España. 724p.

Alagna, F., N. D'Agostino, L. Torchia, M. Servili, R. Rao, M.

Pietrella, G. Giuliano, M. Chiusano, L. Baldoni and G. Perrotta 2009. Comparative 454 pyrosequencing of transcripts from two olive genotypes during fruit development. BMC Genomics 10: 399-414.

Andreini, L., S. Bartolini, D. Chriqui and C. Vitagliano 2008. Histological and immunohistochemical studies on flower induction in the olives tree (Olea europaea L.). Plant Biology 10: 588-595.

Badr, S., H. Hartmann, and G. Martin

1970. Endogenous gibberellins and inhibitors in relation to flower induction and inflorescence development in the olive. Plant Physiol. 46: 674-679.

Ban, T., S. Schiozaki, T. Ogata, and S. Horiuchi

2000. Efect of abscisic acid and shading treatment on the levels of anthocyanin and resveratrol in skin of "Kyoho" grape berry. Acta Hort. 514: 83-89.

Beltrán, G., M. Uceda, M. Hermoso, y L. Frías

2004. Maduración. In: Barranco, D. R. Fernández-Escobar y L. Rallo (eds). 2004. El Cultivo del Olivo. Cuarta edición. Mundi-Prensa. Madrid. España. 724p.

Boss, P., C. Davies and S. Robinson

1996. Expression of anthocyanin biosynthesis pathway genes in red and white grapes. Plant Mol. Biol. 32 (3) 565-569.

Castillo, F., y H. Rapoport

2003. Caracterización morfológica de estados de desarrollo en la yema del olivo (Olea europaea L.). Actas de Horticultura 39: 262-263.

Conde, C., Delrot, S., and Gerós, H.

2008. Physiological, biochemical and molecular changes occurring during olive development and ripening. J. Plant Physiol. 165 (15): 1545-1562.
Criado, M., M. Motilva, M. Goñi, and M. Romero

2007. Comparative study of the effect of the maturation process of the olive fruit on the chlorophyll and carotenoid fractions of drupes and virgin oils from Arbequina and Farga cultivars. Food Chem. 100: 748-755.

Dussi, M.

2007. Intercepción y distribución lumínica en agroecosistemas frutícolas. In: Sozzi, G. (ed). 2007. Árboles frutales, ecofisiología, cultivo y aprovechamiento. Facultad de Agronomía. Buenos Aires. Argentina. 724p.

Fabbri, A., and L. Alerci

1999. Reproductive and vegetative bud differentiation in Olea europaea L. J. Hort. Sci. Biotechnol 74 (4): 522-527.

Fabbri, A., and C. Benelli

2000. Flower bud induction and differentiation in olive. J. Hort. Sci. Biotechnol. 75 (2): 131-141.

Gandul-Rojas, B., M. Roca and M. Mínguez Mosquera

1999. Chlorophyll and carotenoid pattern in olives fruits, Olea europaea cv. Arbequina. J Agric. Food Chem. 47: 2207-2212.

Hackett, W., and H. Hartmann

1964. Inflorescence formation in olives as influenced by low temperature, photoperiod, and leaf area. Bot. Gazette 125 (1): 65-72.

Hartmann, H., A. Heslop, and J. Whisler

1968. Chemical induction of fruit abscission in olives. California Agric. 22 (7): 14-16.

Jiang, Y., D. Joyce, and A. Macnish

2000. Effect of abscisic acid on banana fruit ripening in relation to the role of ethylene. J. Plant Growth Regul. 19: 106-111.

Jiménez, A., E. Izquierdo, F. Rodríguez, J. Dueñas, y C. Tortoza 2000. Determinación de grasas y humedad en aceitunas mediante medidas de reflectancia en infrarrojo cercano. Grasas y Aceites 51 (5): 311-315.

Kitsaki, C., J. Drossopulus, G. Aivalakis, F. Anastasiadou, and C. Delis

1999. In vitro studies of ABA and ethephon induced abscission in olive organs. J. Hort. Sci. Biotechnol. 74 (1): 19-25. 
Loussert, R. y G. Brousse

1980. El Olivo. Mundi-Prensa. Madrid. España. 533p.

Nakano, R., K. Yonemori, A. Sugiera, and I. Kataoka

1997. Effect of gibberellic acid and abscisic acid on fruit respiration in relation to final swell and maturation in persimmon. Acta Hort. 436: 203-214.

Nambara, E., and A. Marion-Poll

2005. Abscisic acid biosynthesis and catabolism. Annu. Rev. Plant Biol. 56: 165-158.

Peppi, M., M. Fidelibus, and N. Dokoozlian

2006. Abscisic acid application timing and concentration affect firmness, pigmentation, and color of "Flame Seedless" grape. HortScience 41 (6): 1440-1445.

Roca, M., and M. Mínguez-Mosquera

2001a. Unusual carotenogenesis in fruits with pronounced anthocyanic ripening (Olea europaea var. Arbequina). J. Agric. Food Chem. 49: 4414-4419.
Roca, M., and M. Míngeuz-Mosquera

2001b. Changes in chloroplast pigments of olive varieties during fruit ripening. J. Agric. Food Chem. 49: 832-839.

Schroeder, J., and E. Nambara

2006. A quick release mechanism for abscisic acid. Cell 126: 1023-1025.

Tous, J., A. Romero, y J. Plana

1998. Comportamiento agronómico y comercial de cinco variedades de olivo en Tarragona. Invest. Agr. Prod. Prot. Veg. 13 (1): 97-109.

Yao Li, C., Weiss, D., and Goldsmith, E.

2003. Effects of carbohydrate starvation on gene expression in citrus root. Planta 217: 11-22.

Zaharia, I., M. Walker-Simmons, C. Rodriguez, and S. Abrams 2005. Chemistry of abscisic acid, abscisic acid catabolites and analogs. J. Plant Growth Regul. 24: 274-284. 
